\title{
PROTON CONDUCTIVE ORGANIC-INORGANIC NANOCOMPOSITE MEMBRANES DERIVED BY SOL-GEL METHOD
}

\author{
Mariia Zhyhailo ${ }^{1}$, Oksana Demchyna ${ }^{1,}{ }^{凶}$, Khrystyna Rymsha ${ }^{1}$, Iryna Yevchuk ${ }^{1}$, \\ Bogdan Rachiy ${ }^{2}$
}

https://doi.org/10.23939/chcht13.04.436

\begin{abstract}
Proton conductive organic-inorganic membranes were synthesized based on acrylic monomers and silica inorganic component, derived as a result of sol-gel transformation of precursor - 3-methacryloxypropyltrimethoxysilane (MAPTMS). Kinetics of polymerization in situ was investigated by laser interferometry. Membranes characterization includes water and methanol uptake, contact angle and proton conductivity at different temperatures. Activation energy values for proton conductivity in prepared membranes were evaluated. The obtained hybrid membranes demonstrated high proton conductivity making them attractive for the use in fuel cells.
\end{abstract}

Keywords: proton conductivity, organic-inorganic membrane, UV-curing, sol-gel process, acrylate, 3-methacryloxypropyltrimethoxysilane.

\section{Introduction}

The growing interest in fuel cells is caused by their environmental safety and the possibility of using renewable fuels [1]. The pioneering works in this field were made by W.R. Grove. With the beginning of space programs in 1960s-1970s, the interest in fuel cells increased: in the Gemini flights polymer electrolyte fuel cells were used, in the Apollo and Space Shuttle program alkaline fuel cells were used. In the past decades, this problem has gained considerable world-wide interest [2-5].

Hydrogen-air fuel cell produces the most environmentally friendly emission - water, however the use of hydrogen as a fuel involves a number of significant difficulties. One limitation is that $5-10 \mathrm{ppm}$ of $\mathrm{CO}$ in $\mathrm{H}_{2}$ feed gas is enough to poison Pt anode electrocatalyst. That

\footnotetext{
${ }^{1}$ Department of Physical Chemistry of Fossil Fuels L.M. Lytvynenko Institute of Physical Organic Chemistry and Coal Chemistry of NAS of Ukraine

3a, Naukova St., 79060 Lviv, Ukraine

${ }^{2}$ Vasyl Stefanyk Precarpathian National University,

57, Shevchenko St., 76018 Ivano-Frankivsk, Ukraine

demchynaoksana@ukr.net

(c) Zhyhailo M., Demchyna O., Rymsha K., Yevchuk I., Rachiy B., 2019
}

is why the use of hydrogen fuel demands its purification from carbon oxide. Electrolysis of water can produce hydrogen of high purity, but the disadvantage of this method is the significant cost of electricity. In addition, a number of difficulties associated with the storage of hydrogen in compressed state and its supply to fuel cells, complicates its use as a fuel.

An alcohol, large-scale production of which is already available and will be expanded in future, seems to be the better fuel for fuel cells [6]. Direct alcohol (methanol and ethanol) fuel cells (DAFC) are very attractive electrochemical systems, since they combine the advantages of a hydrogen-air current source with the possibility of using liquid fuel with storage safety and high volumetric energy capacity. A number of alcohols, and first of all ethanol, can be reproduced in biosystems in unlimited quantities. Although less reactive compared to hydrogen, methanol is considered to be an alternative fuel due to its high energy density, being easier to store and distribute (liquid at atmospheric temperature). Additionally methanol can be easily produced from natural resources (e.g., wood, natural gas and coal) and is biodegradable. In addition, methanol is known to have the best combination between energy density and rate of electro-oxidation [7]. Methanol can be completely electrooxidized to $\mathrm{CO}_{2}$, at temperatures well below $373 \mathrm{~K}$ and, furthermore, it has enough energy density in comparison to that of other fuels [8].

So, at present, DAFC are considered as promising electrochemical systems, however, their characteristics are inferior to those of hydrogen-air fuel cells. For practical implementation of DAFC it is necessary to carry out a considerable amount of fundamental and applied research.

One of the problems that must be solved is the synthesis of an effective proton conductive membrane - a key element in fuel cell. Proton conductivity, which directly determines the fuel cell performance, is the most significant characteristic of a proton exchange membrane. Commercial membranes Nafion have some drawbacks such as high methanol crossover (previously it was found that methanol crossover from the anode to the cathode leads to a DMFC efficiency reduction down to $35 \%$ ), 
high cost, and not functioning well at high temperatures and low humidity. This requires studies on the improvement of Nafion properties and seeking for alternatives to Nafion [9-10].

Among different materials having proton conductivity organic-inorganic nanocomposites seem to be an interesting alternative to Nafion. Utilization of silica modified membranes allows to increase the operating temperature of fuel cell up to $423 \mathrm{~K}$ and current density to $500 \mathrm{~mA} / \mathrm{cm}^{2}$. Liang and co-authors [11] developed Nafion membrane with $10-20 \%$ of silicium diphenyl with nanolayered microstructure providing low crossover. This approach - formation of layered structure for preventing crossover due to improved barrier properties - was developed by $\mathrm{Pu}$ et al. [12]. Peled et al. [13] synthesized poly(vinylidenefluoride) films modified with $\mathrm{SiO}_{2}$ and $60 \% \mathrm{H}_{2} \mathrm{SO}_{4}$, which have $1.5-3 \mathrm{~nm}$ nanopores providing significant decrease in alcohol crossover.

Some new approaches for creation of proton conductive membranes are summarized by Kim and coauthors [14]. In particular, they synthesized the sulfonated $\mathrm{SiO}_{2}$ nanoparticles with uniform core-shell structure by the radical polymerization of vinyl-functionalized silica powders and 4-styrene sulfonic acid sodium salt (SSNa). The resulting material was used as functional fillers for preparing the composite proton conducting membranes for DMFCs. The cell prepared with the composite membranes based on core-shell $\mathrm{SiO}_{2}$ exhibited better cell performance compared to the Nafion1-based cell over the entire range of current density.

One way to obtain an organic-inorganic nanocomposite is a sol-gel technique. This method allows to form filler particles in situ and mix system components on nanoscale, which leads to high homogeneity of particle distribution in polymer matrix and provides an improvement of characteristics of material even at a low degree of filling [15]. Kim and co-workers [16] prepared sulfonated poly(arylene ether sulfone)/phosphotungstic acid modified with silica containing functional group composite membrane. Prior to the preparation of the composite membrane, phosphotungstic acid particles were synthesized with silica compounds using the sol-gel method to achieve solubilization in water. The mechanical and thermal stability as well as proton conductivity were improved because of the strong interaction of the amine groups and sulfonic acid groups in the composite membranes.

An interesting approach was used by Takahashi et al. [17] to obtain organic-inorganic hybrid membranes for fuel cells from 3-glycidoxypropyltrimethoxysilane (GPTMS), N-(3-triethoxysilylpropyl)-4,5-dihydroimidazole (NESPHI) and 1,3-propanesulfone (PS) through a simple one-pot process. The membranes were prepared by the sol-gel method through hydrolysis and condensation reactions of GPTMS, NESPHI and PS at various molar ratios $(\mathrm{GPTMS} / \mathrm{PS}=1: 1,1: 2, \mathrm{NESPHI} / \mathrm{GPTMS} / \mathrm{PS}=$ $1: 1: 2,1: 2: 3,1: 3: 4)$. The ${ }^{29} \mathrm{Si}$ NMR measurements revealed that a siloxane network had formed within the hybrid membranes via the sol-gel process. The hybrid membranes exhibited high proton conductivities.

Takemoto et al. [18] offer another simple one-pot process for the synthesis of organic-inorganic hybrid membranes consisting of an aliphatic main-chain polymer and trisiloxane bond from a trisiloxane derivative, phosphonic acid acrylate, and vinylbenzotriazole. 1,5Divinyl-3-phenylpentamethyltrisiloxane (DPPMTS) was copolymerized with 2-hydroxyethyl methacrylate acid phosphate (HEMAP), and $N$-vinylbenzotriazole (VBT), yielding inorganic-organic hybrid composites. The formation of the inorganic-organic hybrid structure was confirmed by IR, ${ }^{13} \mathrm{C}$, and ${ }^{29} \mathrm{Si}$ NMR spectroscopy. The membranes exhibited good thermal stabilities up to $473 \mathrm{~K}$. The aliphatic chains of the methacrylate derivative copolymerized with trisiloxane in the hybrid membranes improved the mechanical properties of the membranes.

In the present study we prepared novel hybrid organic-inorganic nanocomposites using acrylic monomers and sol-gel precursor 3-methacryloxypropyl trimethoxysilane by polymerization in situ, that is, a combination of UV-initiated polymerization and simultaneous sol-gel process.

\section{Experimental}

Reagents for membrane preparation: acrylonitrile (AN), acrylic acid (AA), potassium 3-sulfopropyl acrylate (SPAK), 3-methacryloxypropyltrimethoxysilane (MAPTMS), ethyleneglycol dimethacrylate (EGDMA), 2,2-dimethoxy-2-phenylacetophenone (DMPA) and phosphoric acid (85\%) were purchased from SigmaAldrich and used as received.

The polymeric parts of the membranes were prepared using AN, AA, SPAK monomers as it is described in [19]. EGDMA was used as a cross-linker. MAPTMS was added to polymerizing system and the whole formulation was stirred for $30 \mathrm{~min}$ at $500 \mathrm{rpm}$. The feed monomer compositions for the preparation of hybrid membranes are summarized in Table 1.

Thin organic-inorganic films were obtained by UV curing technique. For that the prepared photocompositions were placed using graduated pipette into glass molds $(50 \times 20 \times 0.15 \mathrm{~mm})$, covered with glass slide to prevent the inhibiting effect of oxygen and photopolymerized by UV light $(365 \mathrm{~nm})$ at room temperature for $30 \mathrm{~min}$. The obtained films (100-150 $\mu \mathrm{m}$ thick) were washed with a large excess of acetone and water to remove unreacted compounds and dried in an oven at $323 \mathrm{~K}$ until constant weight. 
Feed compositions for hybrid organic-inorganic composites preparation

\begin{tabular}{|c|c|c|c|c|c|}
\hline Sample & AN, wt. p. & AA, wt. p. & SPAK, wt. $p$. & EGDMA, wt. p. & MAPTMS, wt. p. \\
\hline S1 & 40 & 20 & 25 & 15 & - \\
\hline S2 & 40 & 20 & 25 & 15 & 3 \\
\hline S3 & 40 & 20 & 25 & 15 & 5 \\
\hline S4 & 40 & 20 & 25 & 15 & 7 \\
\hline S5 & 40 & 20 & 25 & 15 & 10 \\
\hline
\end{tabular}

The method of laser interferometry was used to investigate the kinetics of photoinitiated polymerization of the prepared reaction systems. The changes in intensity of the interference pattern during contraction of polymerizing compositions were recorded as an interferogram. Relative integral conversion $P$ was determined as the ratio of the current contraction of photocomposition layer to the limiting contraction (at $t \rightarrow \infty$ ). The last was determined as the number of peaks on the interferogram. The results of the experiment were depicted as integral kinetic curves "relative conversion $\mathrm{P}$ - time $\mathrm{t}$ " and their differential anamorphoses. The statistical analysis of experimental kinetic curves was performed using ORIGIN program. In order to increase the assurance of the experimental data, 5 kinetic curves were obtained for each experimental condition, which were then averaged into the form of a single kinetic curve. It is related with the fluctuation sensitivity of the polymerization process, especially at the stage of autoacceleration of polymer chain growth during polymerization.

The evaluation of the completeness of the polymerizing composition curing was carried out by determining of gel-fraction in the synthesized membranes. Extraction of the dissolving fraction was carried out by organic solvents in Soxhlet apparatus for $24 \mathrm{~h}$.

The estimation of the components of the surface energy of polymeric and nanocomposite films was carried out according to the Owens-Wendt equation:

$$
1+\cos \theta=2 \cdot\left[\frac{\left(\gamma_{s}^{d}\right)^{0,5} \cdot\left(\gamma_{l}^{d}\right)^{0,5}}{\gamma_{l}}+\frac{\left(\gamma_{s}^{h}\right)^{0,5} \cdot\left(\gamma_{l}^{h}\right)^{0,5}}{\gamma_{l}}\right]
$$

where $\gamma$ is a surface tension, $\mathrm{mN} / \mathrm{m}$; the lower indices belong to a surface tension of solid $(s)$ and liquid $(l)$; the upper indices $d$ and $h$ denote the components of the dispersion (London) and hydrogen bonding, respectively; $\theta$ is a contact angle.

The values of the surface energy and its components for the liquids used in experiment are as follows [20]: diiodomethane - $\gamma_{1}^{d} 49.5 \mathrm{mN} / \mathrm{m} ; \gamma_{1}^{h} 1.3 \mathrm{mN} / \mathrm{m}$; $\gamma_{1} 50.8 \mathrm{mN} / \mathrm{m}$; glycerin $-\gamma_{1}^{d} 30 \mathrm{mN} / \mathrm{m} ; \gamma_{1}^{h} 34 \mathrm{mN} / \mathrm{m} ; \gamma_{1} 64 \mathrm{mN} / \mathrm{m}$.
Substituting the values of the measured contact angles for wetting of the membrane surface by two fluids into Eq. (1) and solving the system of two equations, one can obtain the values of the dispersion and hydrogen components of the surface energy and the total surface energy.

The surface parts, occupied by the organic and inorganic phases, were estimated using the Cassie-Baxter equation:

$$
\cos \theta=x \cos \theta_{1}+(1-x) \cos \theta_{2}
$$

where $x$ and $(1-x)$ are the parts of the surface, occupied by the sites of I and II types; $\theta_{1}$ and $\theta_{2}$ are the liquid contact angles on the homogeneous surfaces 1 and 2 , respectively; $\theta$ is a contact angle of an investigated surface.

The resistance of polymeric and organic-inorganic membranes was measured at different temperatures by the method of impedance spectroscopy using AUTOLAB impedance spectrometer (EcoChem, the Netherlands) with FRA software equipped by thermostat. The films were placed between the Pt electrodes connected to a computer. Before the measurement the membranes were converted to acid form by immersing them in $0.1 \mathrm{M} \mathrm{HCl}$. Nyquist curves for all the samples were plot over the frequency range $10^{1}-10^{5} \mathrm{~Hz}$. Specific proton conductivity was calculated using the following formula:

$$
\sigma=\frac{l}{R S}
$$

where $R$ is a sample resistance, Ohm; $l$ is a sample thickness, $\mathrm{cm} ; S$ is an electrode-electrolyte contact area, $\mathrm{cm}^{2}$.

Sorption properties of the composite membranes were determined by measuring of the mass difference before and after swelling in water and methanol. Samples were dried at $323 \mathrm{~K}$ till constant weight and placed into distilled water/methanol for $24 \mathrm{~h}$. After that the samples were wiped with filter paper and immediately weighed.

\section{Results and Discussion}

$\mathrm{AA}, \mathrm{AN}$ and SPAK were chosen for the preparation of the organic-inorganic membranes in this study as commercially available monomers. They were 
cross-linked during the photoinitiated copolymerization (the photoinitiator DMPA ( $2 \mathrm{wt} \%$ ) was added to the polymerizing system) using the cross-linker EGDMA (Fig. 1).

Simultaneously sol-gel process occurred due to the presence of MAPTMS. MAPTMS was chosen as a sol-gel precursor since in some recent articles [21, 22] it was regarded as an attractive compound for organic-inorganic composites syntheses: it includes the organic fragment and at the same time methoxysilyl groups, which can be hydrolyzed into silanol groups $\left[-\mathrm{Si}(\mathrm{OH})_{3}\right]$ in water environment and then consequently condensed into crosslinked silica network. Thus, due to polymerization in situ interpenetrating organic-inorganic networks are formed with specific structure providing channels for proton transport.

Kinetic dependencies of free radical crosslinking photoinitiated copolymerization of the above-mentioned polymerizing systems were revealed by means of laser interferometry. The obtained averaged integral and differential curves of photoinitiated polymerization of different polymerizing systems are given in Fig. 2.

All integral kinetic curves of photopolymerization of the investigated system regardless of the content of compositions have a typical S-shape and consist of three stages: (i) an initial section; (ii) a short, but intensive section of autoacceleration; (iii) a long and slow section of autobraking. The maximal rate $w_{\max }$ of polymerization at the acceleration stage, corresponding conversion $P$ and time $\tau_{\max }$ of the achievement of $w_{\max }$ were determined by the method of numerical differentiation of integral kinetic curves (Table 2).

Kinetic parameters, presented in Table 2, indicate the increase in the maximal reaction rate at MAPTMS adding. For example, at adding of $5 \mathrm{wt} \%$ of MAPTMS (the sample S3) $w_{\max }$ was $0.028 \mathrm{~s}^{-1}$ compared to $0.015 \mathrm{~s}^{-1}$ for the formulation without MAPTMS (the sample S1); conversions at $w_{\max }$ are 0.55 and 0.39 , respectively. Time of $w_{\max }$ reaching changes from $5 \mathrm{~s}(\mathrm{~S} 1)$ to $47 \mathrm{~s}(\mathrm{~S} 5)$.

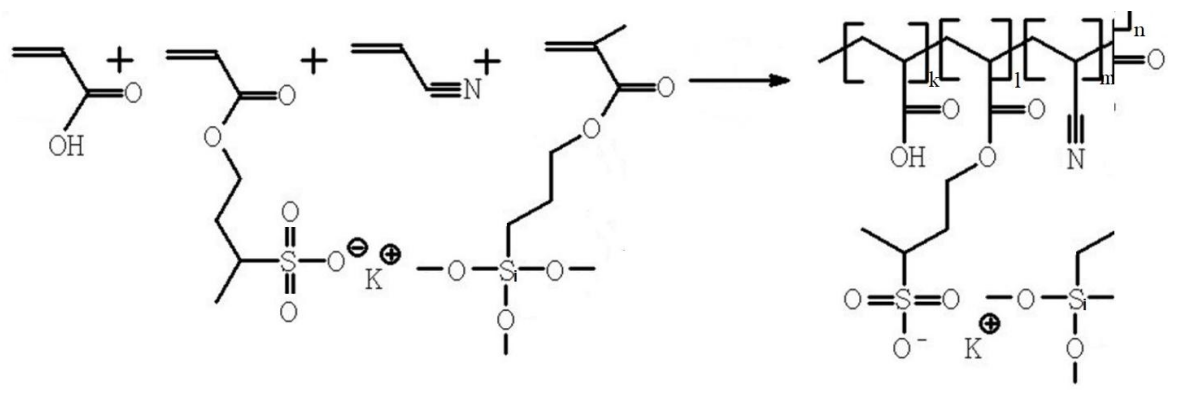

Fig. 1. Scheme of the organic matrix synthesis

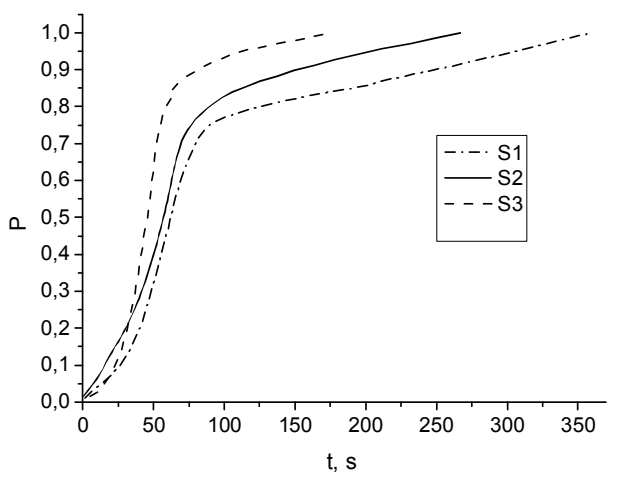

a)

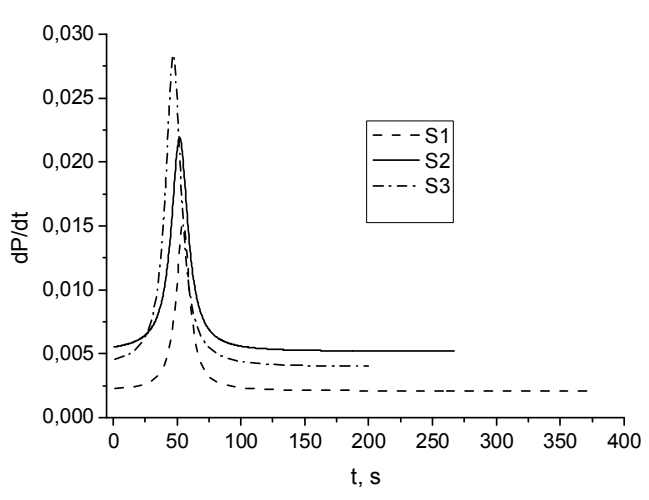

b)

Fig. 2. Integral (a) and differential (b) kinetic curves of photoinitiated polymerization of the samples S1 - S3

Table 2

Kinetic parameters of the process of photoinitiated polymerization

\begin{tabular}{|c|c|c|c|}
\hline Sample & Time of $w_{\max }$ reaching, $\tau_{\max }, \mathrm{s}$ & Conversion $P$ at $w_{\max }$ & Max. rate, $w_{\max }, \mathrm{s}^{-1}$ \\
\hline S1 & 55 & 0.39 & 0.015 \\
\hline S2 & 48 & 0.52 & 0.022 \\
\hline S3 & 47 & 0.55 & 0.028 \\
\hline
\end{tabular}


Hence, conducted studies of the kinetics of photoinitiated polymerization of organic-inorganic systems till deep conversion showed a relationship between the values of such parameters as conversion, the maximal polymerization rate, the time of its achieving, and the ratio monomers : MAPTMS in compositions.

Gel-fraction yields were high, confirming the complete passing of photoinitiated polymerization and formation of cross-linked composite structure in all cases (Table 3). The obtained membranes (150-200 $\mu \mathrm{m}$ thick) were transparent indicating their homogeneous structure. According to Aparicio [23] transparency is the first indication for the homogenization of the organic and inorganic components and no silica domains greater than the wavelength of visible light.

Free surface energy of the series of obtained nanocomposite membranes were evaluated by contact angle measurements. The components of free surface energy (dispersive and hydrogen) of obtained films were calculated using Owens-Wendt equation. The results are summarized in Table 4.

Table 3

Gel-fraction of membranes

\begin{tabular}{|c|c|c|c|c|c|}
\hline Sample & S1 & S2 & S3 & S4 & S5 \\
\hline $\begin{array}{c}\text { Gel-fraction, } \\
\text { wt \% }\end{array}$ & 98.67 & 99.55 & 99.68 & 98.61 & 97.85 \\
\hline
\end{tabular}

Table 4

Values of contact angles and free surface energy for hybrid membranes

\begin{tabular}{|c|c|c|c|c|c|}
\hline Sample & $\begin{array}{c}\theta, \\
\text { degree } \\
\mathrm{C}_{3} \mathrm{H}_{8} \mathrm{O}_{3}\end{array}$ & $\begin{array}{c}\theta, \\
\text { degree } \\
\mathrm{CH}_{2} \mathrm{I}_{2}\end{array}$ & $\begin{array}{c}\gamma_{s}{ }^{d}, \\
\mathrm{mN} / \mathrm{m}\end{array}$ & $\begin{array}{c}\gamma_{\mathrm{s}}^{\mathrm{h}}, \\
\mathrm{mN} / \mathrm{m}\end{array}$ & $\begin{array}{c}\gamma_{s}, \\
\mathrm{mN} / \mathrm{m}\end{array}$ \\
\hline $\mathrm{S} 1$ & 54.0 & 22.8 & 30.45 & 19.50 & 50.95 \\
\hline $\mathrm{S} 2$ & 53.8 & 24.3 & 34.20 & 16.44 & 50.64 \\
\hline $\mathrm{S} 3$ & 53.1 & 25.2 & 35.79 & 14.59 & 50.38 \\
\hline S4 & 51.6 & 28.0 & 36.03 & 13.23 & 49.33 \\
\hline S5 & 50.4 & 29.3 & 37.16 & 11.68 & 48.84 \\
\hline
\end{tabular}

As one can see from the data, presented in Table 4, introducing of MAPMTS into the polymerizing formulations leads to hydrophobization of membrane surface and decreasing of the free surface energy. For comparison, the sample S1 (without the adding of MAPTMS) has the free surface energy of $50.95 \mathrm{mN} / \mathrm{m}$, the sample S5 with $10 \mathrm{wt} \%$ of MAPTMS has the free surface energy of $48.84 \mathrm{mN} / \mathrm{m}$. The hydrogen component of free surface energy also decreases from $19.5 \mathrm{mN} / \mathrm{m}$ for the sample $\mathrm{S} 1$ to $11.68 \mathrm{mN} / \mathrm{m}$ for the sample $\mathrm{S} 5$, while the dispersive component increases from 30.45 to $37.16 \mathrm{mN} / \mathrm{m}$.
By the Cassie-Baxter equation the fractions of the membrane surface, occupied by the inorganic phase (IP), are estimated for the synthesized organic-inorganic membranes (Fig. 3). These results confirm that the synthesis of membranes has been conducted successfully, since the ratio of the organic and inorganic components in the composites corresponds to the initial compositions of the polymerization mixtures.

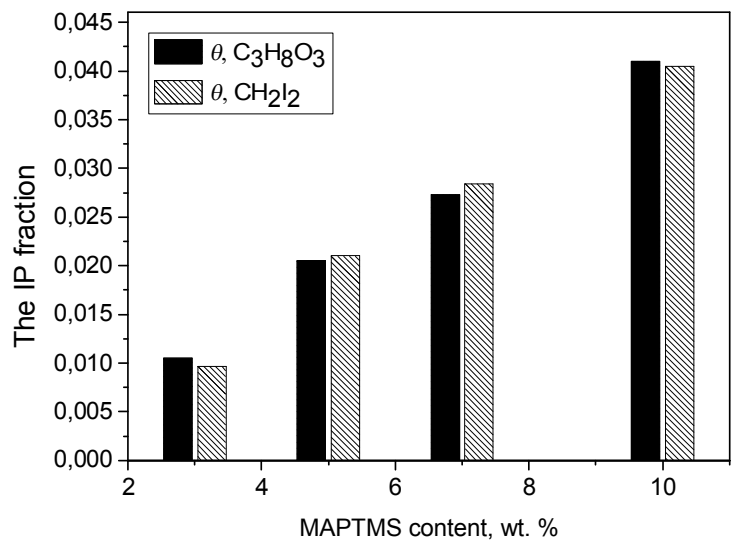

Fig. 3. The IP fraction of the membrane surface $v s$ MAPTMS content in the sample (calculated after the contact angles of wetting of the surface by glycerin and diiodomethane)

In Fig. 4, the histograms of the distribution of the contact angles of wetting of the polymeric and organicinorganic membranes surfaces by glycerin are presented. The addition of precursor MAPTMS caused the formation of silica clusters as a result of sol-gel process. Kinetic parameters show the increasing in polymerization rate at addition of MAPTMS, confirming the occurring of the sol-gel transformation of precursor, which also contributes to the system conversion. Silica clusters and polymer chains form organic-inorganic structure due to hydrogen bonding. The formation of more compact structure makes contact angle distribution narrower for the polymer-inorganic nanocomposites with larger content of MAPTMS.

Water and methanol uptake (WU, MU) are significant characteristics for proton conductive materials. Water medium enhances proton transport through the material. At the same time too high water uptake worsens dimensional stability of membranes. The results obtained are presented in Fig. 5.

Water uptake values for the investigated membranes decrease with the increase of MAPTMS content, which correlates with the data of contact angle measurement and confirms hydrophobization of the nanocomposite material at MAPTMS adding. Methanol uptake demonstrates the same tendency. The values of methanol uptake are relatively low (MU of hybrid membrane at MAPTMS content of $10 \mathrm{wt} \%$ is equal to $8.8 \%$ ), providing the possibility to use the synthesized nanocomposites in methanol fuel cells. 


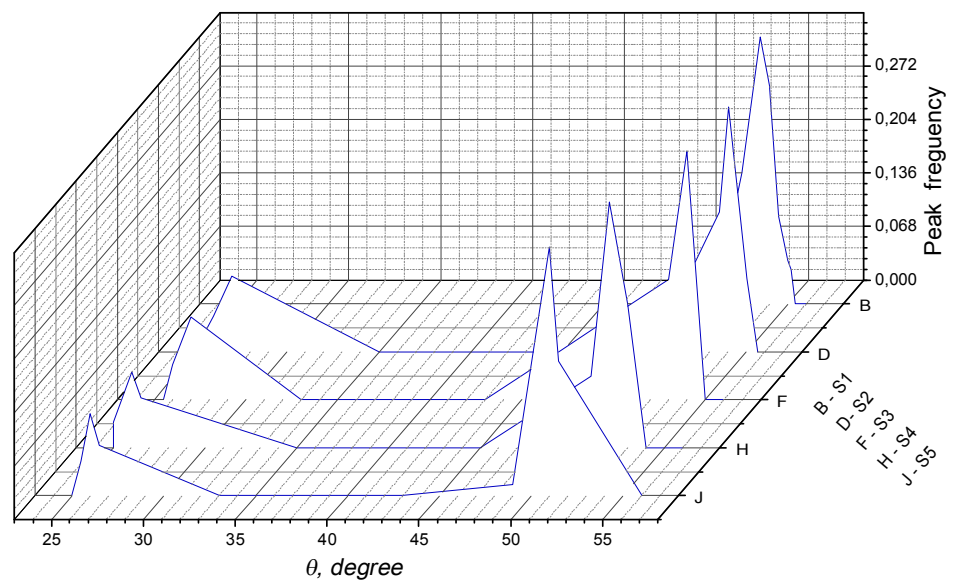

Fig. 4. Distribution histograms of the contact angles of wetting of the membrane surface by glycerin: B - S1; D - S2; F - S3; H - S4; J - S5

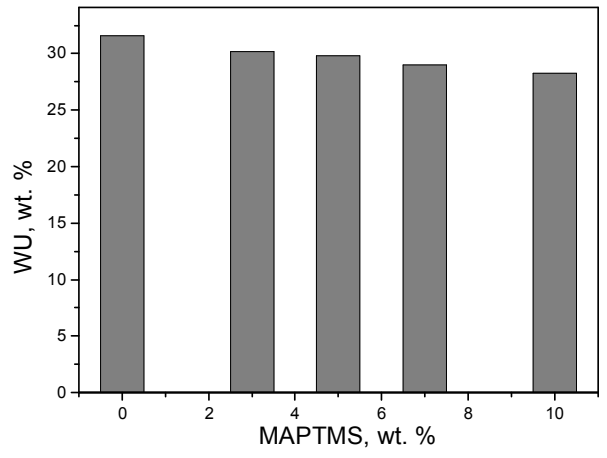

a)

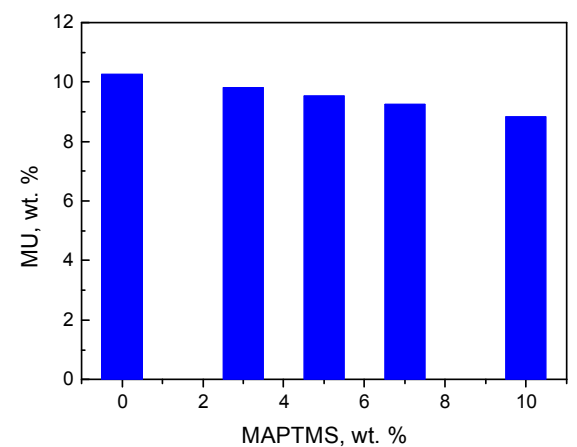

b)

Fig. 5. WU (a) and MU (b) as a function of MAPTMS content at $323 \mathrm{~K}$

Table 5

Proton conductivity of membranes at different temperatures

\begin{tabular}{|c|c|c|c|c|c|}
\hline Sample & $\sigma$ at $293 \mathrm{~K}, \mathrm{Sm} / \mathrm{cm}$ & $\sigma$ at $313 \mathrm{~K}, \mathrm{Sm} / \mathrm{cm}$ & $\sigma$ at $323 \mathrm{~K}, \mathrm{Sm} / \mathrm{cm}$ & $\sigma$ at $333 \mathrm{~K}, \mathrm{Sm} / \mathrm{cm}$ & $E, \mathrm{~kJ} / \mathrm{mol}$ \\
\hline S1 & $8.8 \cdot 10^{-4}$ & $1.5 \cdot 10^{-3}$ & $2.310^{-3}$ & $2.98 \cdot 10^{-3}$ & 14.6 \\
\hline S2 & $5.1 \cdot 10^{-3}$ & $7.6 \cdot 10^{-3}$ & $9.7 \cdot 10^{-3}$ & $1.06 \cdot 10^{-2}$ & 12.6 \\
\hline S3 & $6.3 \cdot 10^{-3}$ & $9.8 \cdot 10^{-3}$ & $1.0210^{-2}$ & $1.1210^{-2}$ & 11.6 \\
\hline S4 & $4.9 \cdot 10^{-3}$ & $7.5 \cdot 10^{-3}$ & $8.7 \cdot 10^{-3}$ & $1.00 \cdot 10^{-2}$ & 12.6 \\
\hline S5 & $3.8 \cdot 10^{-3}$ & $5.2 \cdot 10^{-3}$ & $7.6 \cdot 10^{-3}$ & $9.38 \cdot 10^{-3}$ & 13.6 \\
\hline
\end{tabular}

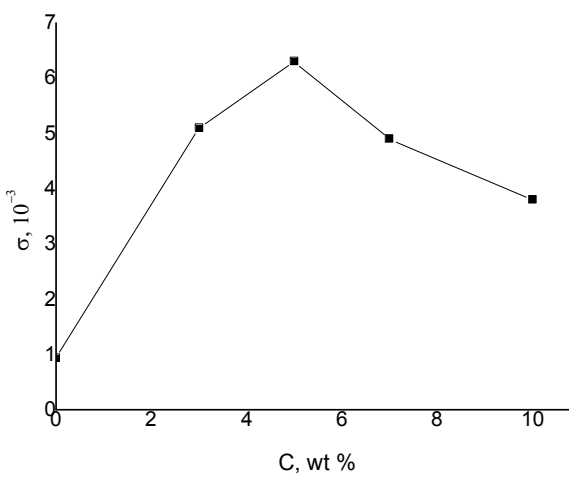

Fig. 6. Proton conductivity as a function of MAPTMS content at $293 \mathrm{~K}$

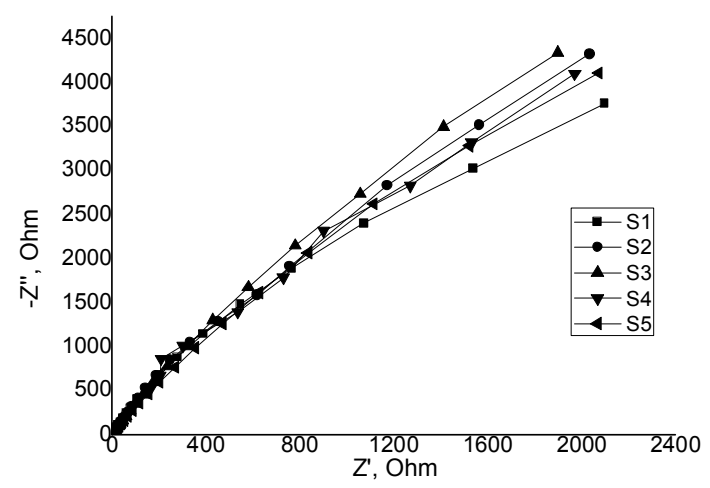

Fig. 7. Nyquist diagrams for the samples at $313 \mathrm{~K}$ 


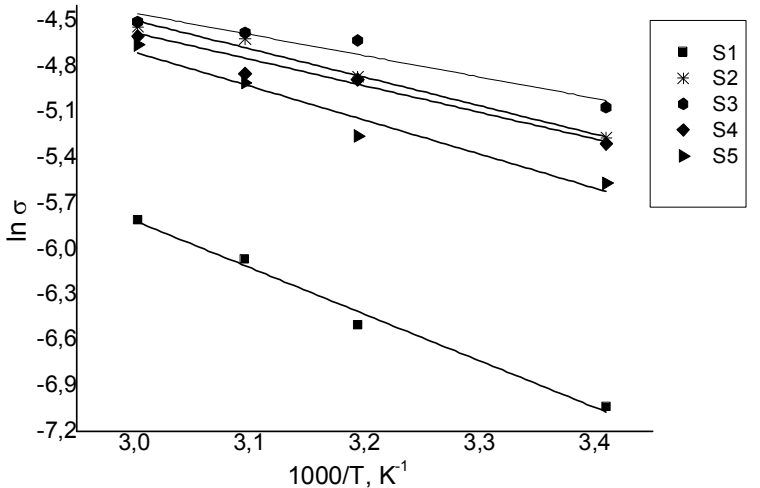

Fig. 8. Thermal dependencies of $\sigma$ in the Arrhenius coordinates

Proton conductivities of three synthesized organicinorganic nanocomposite membranes were measured as a function of temperature and MAPTMS weight fraction (Figs. 6, 7 and Table 5). Before measurement the membranes were converted to acid form by immersing in $0.1 \mathrm{M} \mathrm{HCl}$. Proton diffusion through membrane can be described by the Grotthus mechanism [24].

The synthesized hybrid organic-inorganic membranes demonstrated high level of proton conductivity $10^{-4}-10^{-2} \mathrm{Sm} / \mathrm{cm}$. The proton conductivity of the sample $\mathrm{S} 3\left(1.12 \cdot 10^{-2} \mathrm{Sm} / \mathrm{cm}\right)$ at $333 \mathrm{~K}$ was quite comparable to that of Nafion-117 $\left(1.52 \cdot 10^{-2} \mathrm{Sm} / \mathrm{cm}\right)$.

It can be seen that with the increase in MAPTMS content an increase in conductivity was achieved: for example, at $293 \mathrm{~K}$ the proton conductivity of the sample S1 (without added MAPTMS) was $8.8 \cdot 10^{-4} \mathrm{Sm} / \mathrm{cm}$ while the proton conductivity of the sample S2 (3 wt \% MAPTMS) was equal to $5.1 \cdot 10^{-3} \mathrm{Sm} / \mathrm{cm}$. It can be explained by formation of hybrid structure, facilitating proton mobility due to the proton transfer pathways saturated by free water able to hydrate the sulfonated and $\mathrm{Si}-\mathrm{OH}$ groups. However, at further increasing of MAPTMS content we observe decreasing of proton conductivity (Fig. 6). It is consistent with the larger hydrophobicity of the sample S5. The maximal value of proton conductivity in the investigated temperature interval was observed for the sample S3 (5 wt \% of MAPTMS).

All nanocomposite membranes exhibited an increasing conductivity with increasing temperature within the temperature range investigated since proton conduction is a thermally activated process. It allowed to estimate the activation energy for proton conduction using the Arrhenius equation:

$$
\sigma=A \exp \left(-\frac{E}{k T}\right)
$$

where $\sigma$ is the proton conductivity, $\mathrm{Sm} / \mathrm{cm} ; T$ is the absolute temperature, $\mathrm{K} ; k$ is the Boltzmann constant, $\mathrm{J} / \mathrm{K}$; $A$ is the preexponential factor, $E$ is the activation energy, $\mathrm{J} / \mathrm{mol}[25]$.

Fig. 8 shows the temperature dependencies of the proton conductivity of the samples in the coordinates $\ln \sigma-1 / T$. The linear shape of these dependencies with a regression coefficient close to $1\left(R^{2}=0.9-0.97\right)$ confirms that the change in proton conductivity with increasing temperature is of the Arrhenius type. Activation energy values are comparable to those of the similar systems reported in the literature [26, 27].

The increase in conductivity with increasing temperature is caused by an increase in the free volume of the system. In this case, the segmental motion of polymer molecules is intensified, which allows ions to jump from one place to another and provides a path for ion movement [25].

\section{Conclusions}

The proton conductive hybrid organic-inorganic membranes were prepared via photoinitiated radical polymerization of acrylic monomers in the presence of cross-linker and simultaneous sol-gel transformations of the inorganic part of the organic-inorganic precursor MAPTMS. We suggest using the accessible materials for membrane producing. This route also does not require previous complex syntheses. It makes this approach less costly and more time-consuming compared to others.

Kinetic dependencies of free radical cross-linking photoinitiated copolymerization of polymer-inorganic systems indicate a relationship between the values of the conversion, the maximal polymerization rate, the time of $w_{\max }$ achieving, and the content of sol-gel system added. Free surface energy of membranes and its components were found to change depending on the membrane content: the increase in inorganic component made the membranes structure denser and more hydrophobic.

Due to the formation of specific nanostructure of organic-inorganic materials hybrid polymer-inorganic membranes exhibited promising properties: high proton conductivity (up to $1.12 \cdot 10^{-2} \mathrm{Sm} / \mathrm{cm}$ at $333 \mathrm{~K}$ ), relatively low water and methanol uptake. Proton conductivities of membranes were measured at four temperatures. The temperature dependencies in the Arrhenius coordinates demonstrated the linear shape, which allowed to calculate the activation energy of the proton transportation process $(11.6-14.6 \mathrm{~kJ} / \mathrm{mol})$. The obtained results indicate that UVcured cross-linked membranes offer a significant potential for application in DAFC. 


\section{References}

[1] Liu Y.-L.: Polym. Chem., 2012, 3, 1373.

https://doi.org/10.1039/c2py20106b

[2] Devanathan R.: Energy Environ. Sci., 2008, 1, 101. https://doi.org/10.1039/b808149m

[3] Xu T., Wu D., Wu L.: Prog. Polym. Sci., 2008, 33, 894. https://doi.org/10.1016/j.progpolymsci.2008.07.002

[4] Ahmad H., Kamarudin S., Hasran U. et al.: Int. J. Hydrogen Energy, 2010, 35, 2160.

https://doi.org/10.1016/j.ijhydene.2009.12.054

[5] Elabd Y., Hickner M.: Macromolecules, 2011, 44, 1.

https://doi.org/10.1021/ma101247c

[6] Tarasevych M., Kuzov A.: Int. Sci. J. for Alternative Energy and Ecology, 2010, 7, 86.

[7] Aricò A., Srinivasan S., Antonucci V.: Fuel Cells, 2001, 1, 133. https://doi.org/10.1002/1615-6854(200107)1:2<133::AID-

FUCE133>3.0.CO;2-5

[8] Silva V., Mendes A., Madeira L. et al.: Advances in Fuel Cells, 2005, 24 p.

[9] Dupuis A.: Prog. Mater. Sci., 2011, 56, 289.

https://doi.org/10.1016/j.pmatsci.2010.11.001

[10] Park C., Lee C., Guiver M. et al.: Prog. Polym. Sci., 2011, 36, 1443. https://doi.org/10.1016/j.progpolymsci.2011.06.001

[11] Liang Z., Zhao T., Prabhuram J.: J. Membr. Sci., 2006, 283, 219. https://doi.org/10.1016/j.memsci.2006.06.031

[12] Pu C., Huang W., Ley K. et al.: J. Electrochem. Soc., 1995, 142, L119. https://doi.org/10.1149/1.2044333

[13] Peled E., Duvdevani T., Aharon A. et al.: Solid State Lett., 2000, 3, 525. https://doi.org/10.1149/1.1391198

[14] Kim D., Jo M., Nam S.: J. Ind. Eng. Chem., 2015, 21, 36. https://doi.org/10.1016/j.jiec.2014.04.030

[15] Ogoshi T., Chujo Y.: Composite Interfaces, 2005, 11, 539. https://doi.org/10.1163/1568554053148735

[16] Kim D., Lee B., Nam S.: Thin Solid Films, 2013, 546, 431. https://doi.org/10.1016/j.tsf.2013.05.121

[17] Takahashi K., Umeda J., Hayashi K. et al.: J. Mater. Sci., 2015, 51, 3398. https://doi.org/10.1007/s10853-015-9654-0

[18] Takemoto M., Hayashi K., Sakamoto W.: Polymer, 120, 264. https://doi.org/10.1016/j.polymer.2017.05.065

[19] Demydova Kh., Horechyy A., Yevchuk I. et al.: Chem. Chem. Technol., 2018, 12, 58. https://doi.org/10.23939/chcht12.01.058
[20] Samaryk V., Voronov A., Tarnavchyk I. et al.: Prog. Org. Coat., 2012, 74, 687. https://doi.org/10.1016/j.porgcoat.2011.07.015 [21] Kapoor P., Mhaske S., Joshi K.: Prog. Org. Coat., 2016, 94, 124. https://doi.org/10.1016/j.porgcoat.2015.11.021

[22] Costa R., Lameiras F., Nunes E. et al.: Ceram. Int., 2016, 42, 3465. https://doi.org/10.1016/j.ceramint.2015.10.145

[23] Aparicio M., Duran A.: J. Sol Gel Sci. Technol. 2004, 31, 103. https://doi.org/10.1023/B:JSST.0000047969.56298.d7

[24] Kreuer K.: Chem. Mater., 1996, 8, 610. https://doi.org/10.1021/cm950192a

[25] Ying L., Jiang-Hong G., Yu-Sheng X.: Acta Phys.-Chim. Sin., 2001, 17, 792. https://doi.org/10.3866/PKU.WHXB20010906 [26] Park Y.-I., Moon J., Kim H.: Electrochem. Solid State Lett., 2005, 8, A191. https://doi.org/10.1149/1.1862472

[27] Kim H., Prakash S., Mustain W. et al.: J. Power Sour., 2009, 193, 562. https://doi.org/10.1016/j.jpowsour.2009.04.040

Received: July 27, 2018 / Revised: December 12, 2018 / Accepted: February 12, 2019

\section{ПРОТОНОПРОВІДНІ ОРГАНО-НЕОРГАНІЧНІ НАНОКОМПОЗИТНІ МЕМБРАНИ, ОДЕРЖАНІ ЗОЛЬ-ГЕЛЬ МЕТОДОМ}

Анотація. На основі акрилових мономерів та кремнеземної неорганічної складової, сформованої у результаті зольгель перетворення прекурсора - 3-метакрилоксипропілтриметоксисилану (МАПТМС), синтезовано протонопровідні органо-неорганічні нанокомпозитні мембрани. Методом лазерної інтерферометрії досліджено кінетику полімеризаиії in situ. Встановлено водопоглинання мембран $і$ набрякання їх у метанолі, виміряно контактні кути змочування, що дало змогу розрахувати вільну поверхневу енергію мембран та ії складові. Досліджено протонну провідність мембран за різних температур, оиінено енергію активачії протонної провідності. Одержані гібридні мембрани демонструють високу протонну провідність, щзо дає можсливість використовувати їх у паливних комірках

Ключові слова: протонна провідність, органонеорганічна мембрана, УФ-затвердження, золь-гель процес, акрилат, 3-метакрилоксипропілтриметоксисилан. 